\title{
How formal institutional antecedents affect Tunisian venture creation decision scripts
}

\author{
Abdallah Haj brahim $^{1} \cdot$ Salim Morched ${ }^{1} \cdot$ Younes Boujelbene $^{1}$ \\ Received: 7 March 2019 / Accepted: 1 October 2019 / Published online: 23 June 2021 \\ (C) The Author(s) 2021
}

\begin{abstract}
The aim of this paper is to reveal the impact of three Tunisian formal institutional systems on their venture creation decision through the study of entrepreneurial scripts of Tunisians nascent entrepreneur post-revolution phase. The method adopted in this study is the cognitive map. This research enriches entrepreneurial process literature by examining a finer-grained linkage between the degree of the development of Tunisian formal institutional systems and the level of expertise in the decision stage as an early process of venture creation. To do this, the cognitive approach is adopted by using the structural analysis method as a tool for structuring ideas and collective reflections. In the field of entrepreneurship, the mentioned approach has been the subject of few empirical studies. This leads to a better understanding of individual's cognitive universe (actors, coaches, managers, entrepreneurs, etc.). It is important in the context of this study to identify and analyze the influence of formal institutional antecedents on the cognition of Tunisian nascent entrepreneurs and consequently on their decision. Experiments done on 120 born entrepreneurs incubating in the nurseries allowed to present, in the form of a collective map, the formal institutional antecedents that seem to affect their decisions to become entrepreneurs through their NVCD scripts.
\end{abstract}

Keywords Venture creation decision $\cdot$ Formal institutions $\cdot$ Tunisia post-revolution

\section{Introduction}

The creation of a new venture has been considered today as an engine of growth and has become a strategic element in the evolution of the economies of the countries. Moreover, in a context of globalization, where the world is vibrating at the accelerated pace of technological inventions and advances (Masmoudi \& Zouiten, 2007), most developed and emerging countries have been interested in small- and medium-sized enterprises, because they contribute to create jobs, reduce poverty, activate competition, and improve productivity. The combination of these measures stimulates economic

Abdallah Haj brahim

radhoui12@yahoo.fr

Salim Morched

slimmorched@hotmail.com; salimmorched.mez@gmail.com

Younes Boujelbene

younes.boujelbene@gmail.com

1 Department of Management, Faculty of Economics and Management, University of Sfax, Street of Airport, km 4.5, 3018 Sfax, LP 1088, Tunisia development. Given the importance of ensuring the creation of viable enterprises, accompanying systems and support have gradually become developed (Fayolle, 2002), to provide for the future entrepreneurs easy access to the necessary resources (Albert \& Large, 2002). Indeed, by the early 1970s, the majority of developed countries had embarked on a policy of support for business creation. The USA is regarded as the pioneer of the field, since it displays a certain advance in support practices and a better knowledge made possible by the various experiences of its states (Masmoudi \& Zouiten, 2007). European countries have become aware of the need to develop and support mechanisms for business startups in the 1980s.

Tunisia's promotion of private investment dates back to the early 1990s. Through the development of entrepreneurial culture, which has tried to change the wage mentality of young Tunisians to an entrepreneurial mentality, and in this respect, 11 from 14 universities in Tunisia introduce the "entrepreneurship education" course and support for the realization of the Business Model and Business Plan, as well as personal coaching. Therefore, to improve the creation, reform, and promotion conditions of small enterprises, the Tunisian government puts technical assistance and legal facilitation of procedures to the launch of companies, the follow-up projects, and 
networking. Most of these structures are attached to ministries of industry, agriculture, employability, and trade. At this level, there are many created structures like the Agency for the Promotion of Industry and Innovation (APII), the National Network of Business Incubators, the Agency for the Promotion of Agricultural Investments (APIA), the Business Centers, the National Agency for Employment and Independent Labor (ANETI), technical centers, techno poles, and the Center for the Promotion of Exports (CEPEX). The unavoidable link in the value chain of business creation remains the aim of financing new ventures.

The revolution of 14 January 2011 was a real wake-up involving the government to consider these matters. Indeed, policymakers were more sensitive to the importance of entrepreneurship. The government transition knew that there was an important gap in terms of venture funding. According to the Jasmin Plan (October, 2011), Tunisian government created two main funds. The first one is a fund of funds called "Ajyal Funds," which is composed of a PE fund and other sub-funds focused on the infrastructure of sectors, including renewable energy. This fund is expected to generate a return of $\$ 30$ billion and create more than one million jobs. The second fund is named "Deposit and Consignment Fund" (CDC) and it will mainly focus on investing in infrastructure and supporting SMEs. Improving infrastructure will facilitate the creation of new businesses, especially within interior regions. The CDC will offer a new array of financial instruments, which will be backed by the government, along with new funding opportunities to early-stage businesses.

Despite these supports, the venture creation rate is still few, and there are enormous challenges that inhibit the entry rate of firm formation. The survey on the Transition from School of Life Active in Tunisia, financed by the project of the Bureau International Labor Organization (ILO) "Work4Youth," the MasterCard Foundation, and the Analysis prepared by the National Observatory of Employment and Qualifications (ONEQ), showed that young people opt for a small proportion for work independent. Of all young people in employment, only $7.8 \%$ work as self-employed, and $2.7 \%$ as employers.

In fact, studying the impacts of these supports becomes very crucial, in the sense it permits to determine in-depth the degree of correlation between these entrepreneurial facilities offered by the Tunisian government post-revolution and their target audience (young graduates). Responding to this need, Busenitz et al. (2000) have developed and tested a measure for a country's institutional profile for entrepreneurship. Using this measure, actually it is possible to study peoples' perceptions of institutions ranging from highly negative to very positive. This study of

Paturel (2015) presents advantages because it could contribute to the adventure formulation of these formal institutions as important antecedents to the decision to become an entrepreneur. Indeed, it will enrich the knowledge in this domain, because there are few studies about antecedents, and no secondary or university formation gives us enough material to study this subject, although such surveys and analysis are very costly (Parutel \& Boukhris, 2015).

Samadi (2019) announced that there are various studies based on institutional and non-institutional factors in developing the level and nature (or types) of entrepreneurship. In these studies, there has been no attention to the causal relationship between these variables. The direction of the causality from institutions to entrepreneurship is considered unidirectional. Furthermore, the current studies have only investigated the role of institutional factors in developing entrepreneurship for a short run and there was no attention for a long run.

The main objective is to expose the perception of Tunisian nascent entrepreneurs at the level of entrepreneurial formal institutions through drawing their collective cognitive map. This paper extends to entrepreneurship literature and previous studies such as M. Dziri (2013) and and Parutel \& Boukhris (2015) by proposing a new approach to build an average cognitive map for the explanation of Tunisian entrepreneurial formal institutions weakness.

This paper proceeds as follows: The first part is a review of the literature that relates entrepreneurial scripts and institutional context of the venture creation decision (VCD), which presents the foundation of the conceptual linkage, which will be investigated later. The next step is the exploration of the extent to which three principal institutional arrangements (legal system, financial system, and educational system) influence the cognitions of Tunisian nascent entrepreneurs. The overall is then an empirical examination of these relationships using a sample of 150 nascent entrepreneurs. Finally, the results and implications of this study will be discussed for future research and practice.

\section{Literature review}

\section{Entrepreneurial cognition: arrangement, willingness, ability scripts}

Script analysis has been considered primarily as the theory of expert information processing in order to examine differences between entrepreneurs and non-entrepreneurs as regards decision-making and is rooted in the following idea: entrepreneurs develop unique knowledge structures and their process (transform, store, recover, and use) information differently from then on-entrepreneur (Randolph-Seng et al., 2015; Shepherd \& Patzelt, 2017). Thus, according to the theory of expert information processing, entrepreneurs are experts in the field of entrepreneurship and through deliberate practice (Henry et al., 2006), who can acquire entrepreneurial cognitions; that is, scripts or knowledge structures that allow them to use the information significantly better than non-expert entrepreneurs. 
In the case of entrepreneurs, the entry and doing action thresholds of expert information processing theory are parallel to the theoretical (Shapero \& Sokol, 1982) and empirical (Krueger \& Carsrud, 1993) action thresholds that explain individual intentions to form a new venture. Thus, the entry (the beginning processes of organizational formation) depends specifically upon feasibility arrangements, resources from that environment such as capital, opportunity, and contacts, but doing depends effectively upon a combination of ability and willingness.

The information-processing conceptualization of cognition had long been considered a mainstream for decision-making (Mitchell, 2011). Since the seminal work by Peng et al. (2009), a comprehensive psychological approach has been done to study a new venture creation by focusing on the choice-based cognitive processes at the entrepreneur level of analysis. Other researchers were also more and more focusing on an information-processing approach to understand entrepreneurial attitudes, decision-making, and thought processes (Bird, 1992). Cognition theory has been developed to the point where three types of cognitive scripts (arrangements, ability, and willingness) have been found to be central to the venture creation decision (Mitchell et al., 2000; Smith et al., 2009).

Arrangement scripts There is an entry on how scripts relate to the individual knowledge of certain structures to achieve the necessary agreements and participate in business activity (Lam et al., 2011). These structures include possession and specific use of an idea; a single network of contacts and usage; possession or access to specific resources to start a business; they include a predictable idea, access to resources, and venture specific skills and specific entrepreneurial abilities that allow generating a competitive advantage to the new business (Mitchell et al., 2000).

Venture willingness scripts the doing structure Venture willingness scripts the doing structure support the entrepreneur's commitment to venturing and their receptivity to the idea of starting a new venture. They include seeking focus, commitment, tolerance, and opportunity motivation. Increasing the motivation to make VCD (Krueger, 1993), which provides a precondition for script doing/enactment (Krueger, 1993).

Venture ability scripts Venture ability scripts are the capabilities, skills, knowledge, norms, and attitudes that individuals require to create a venture, such as ability, opportunity fit, venturing diagnostic ability, and venture situational knowledge (Mitchell et al., 2002). At least three scripts relating to ability appear in the business literature: Diagnostic scripts concern the ability to assess the condition and potential of ventures and to understand the systematic elements involved in their creation. Situational knowledge scripts involve the ability to draw on the lessons learned in a variety of ventures and apply those lessons to a specific situation. Opportunity recognition scripts have to do with the ability to see ways in which customer and venture value can be created in new combinations of people, materials, or products.

\section{Formal institutional antecedents and cognition of entrepreneur's relationship}

Institutional context impacts economic behavior (Peng et al., 2009), entrepreneurship in general (Baumol, 1990), and entrepreneurial cognitions in particular (Busenitz \& Lau, 1996; Mitchell et al., 2000). It is widely accepted that institutions influence economic behaviors within the business system by generating and reproducing certain cognitive assumptions taken for granted by the members of the society (Scott, 2008a, b). Accordingly, we infer that institutional arrangements (that is, features of financial systems and other sociopolitical infrastructures) encourage or discourage entrepreneurship and that individual cognitive scripts mediate this process.

The best known of these research studies, which investigate the causal relationship between institutions and entrepreneurship, have been ignored in existing analyses. In the vast majority of studies (Samadi, 2019), the relationship between these two variables has been investigated without any attention to the level of economic growth and development of countries. Recently, there have been few studies (e.g., Henrekson \& Sanandaji, 2011; and Samadi, 2018) that discuss or test the (bidirectional) causality between institutions and entrepreneurship. In these studies, despite the causal relationship between these two variables being investigated as theoretically or basically causality tested, the level of economic development of countries is ignored.

These institutions' impact not only the level of entrepreneurship but also the characteristics and quality of entrepreneurship initiatives, by making them more or less productive (Bruton et al., 2010; Baumol, 1990). A well-established distinction differentiates between formal and informal institutions (Sobel, 2008). The formal ones refer to the political, legal, and economic rules designed to limit individual behavior and facilitate exchanges, while informal institutions include behavior, values, or beliefs in a society.

Formal institutions can be understood in a very broad sense. The purpose of government policies should be to guarantee that the mechanisms of the market work efficiently by eliminating market failures and possible administrative rigidities, all with the goal of creating a context that allows companies to assume reasonable risks in the running of their business. Lim and Schoenung (2010) research on formal institutional influences in entrepreneurial cognitive and decisionmaking processes has shown that individuals in countries with less complex regulatory regimes and more property rights protection generally show higher levels of venture 
arrangements and willingness scripts. Bosma and Schutjens (2011) have added that the identified positive relation between strong entrepreneurial attitudes, and subsequent entrepreneurial activities are not straightforward. There are national formal institutional forces at play, which, at the individual level, empower or deter the decision to indeed start a business.

Institutional conditions have an impact on the delivery of entrepreneurship, because of their ability to influence the skills, resources, and preferences of individuals. Thus, a functional business environment provides positive incentives for entrepreneurs (Davidsson \& Henrekson, 2002). By contrast, a feeble institutional environment can influence characteristics such as quality of governance and access to capital and other resources and affect the perceptions of entrepreneurs (Acs et al., 2008). Accordingly, entrepreneurial activity will be context-specific and significantly connected to the character of the institutional environment (Hwang \& Powell, 2005).

\section{Legal system and VCD scripts}

Practically, all economies have a government charged with laying down rules, laws, and regulations and with administering a judicial system to enforce them. By these activities, the government fosters the development of markets and shape economic behavioral norms. The government also directly affects resource allocation and market behavior through its tax, fiscal, monetary, and other economic policies. A government is an institution because it is normally responsible for setting up and enforcing the rules of the game.

The recent multi-country research by Stenholm et al. (2013) has suggested that regulatory frameworks tend to have a stronger effect on entrepreneurial activity than on informal institutions. Nystrom (2009) supports this line of argument with a cross-country study that found that a smaller government sector, well-developed legal structure and security of property rights, and less strict regulation of credit, labor, and business are positively related to the entrepreneurial activity. Another key determinant of the regulatory dimension is the regulation and laws (Matlay et al., 2010). Which determinant determines the level of access to resources required to create new ventures? For example, the more protective regulations of intellectual property exist, the more motivation for individuals starting businesses increase. Baker \& Nelson (2005) also pointed out that if the institutional environment does not support entrepreneurship, the perception of entrepreneurs of potential business opportunities would be hindered. In contrast to developing countries, developed countries tend to have more advanced institutions with friendlier regulations toward entrepreneurship. Developed countries also tend to have more jobs and more economic freedom (McMullen et al., 2008). Better protection of copyright and intellectual property, less regulatory complexity and corruption, increased transparency, and better functioning capital markets are available in these countries (Lee et al., 2007; Lim \& Schoenung, 2010; Xavier et al., 2013). Some researchers suggest that lower taxation determines firm birth in the economy, generating employment opportunities, and fostering investments and economic growth (Da Rin et al., 2011). Strict national regulations on new firms may discourage individuals from thinking of starting a new business (Bosma, 2009).

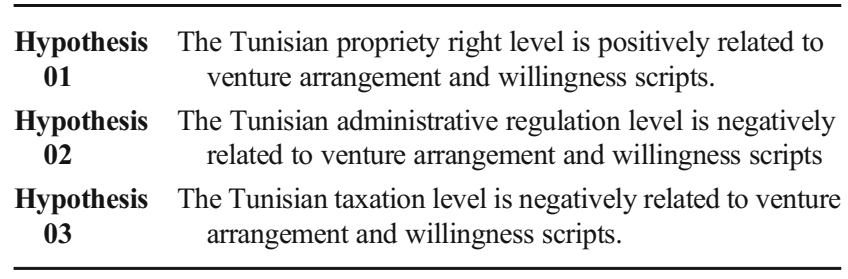

\section{Financial system NVCD scripts}

Another key institutional factor is access to financial capital (Bowen \& De Clercq, 2008; Urbano \& Guerrero, 2013). Bowen and De Clercq (2008) found strong positive correlations between the growth of entrepreneurship and the availability of financial capital. The more financial capital is targeted to the potential entrepreneur, the higher the percentage of nascent entrepreneurship is. Otache (n.d.) mentions two environmental antecedents of entrepreneurial intentions, including access to capital (Lüthje \& Franke, 2003) and knowledge of the potential business sector (Kristiansen \& Indarti, 2004). Van Stel et al., (2007) found that the probabilities of establishing a new company decrease when only the minimum capital required for starting the new business increases. It is generally acknowledged that individuals starting a new business are particularly vulnerable to financial constraints; entrepreneurs often require substantial outside financing owing to the limited personal wealth (Caputo \& Dolinsky, 1998). The inconveniences of some banks (TSB) reside in the waiting period, which is relatively long, and the non-approval of working capital in cash is a very important condition for certain types of projects that need it. Overall, other banks like BFPME require real and personal guarantees and ask for other confirmed credits allocated by commercial banks. In general, the paperwork that each promoter needs to successfully convince state and commercial banks remains still heavy. Business plans and technical competence are quite often insufficient for the acceptance of the application for funding (Ouanes \& Rejeb, 2016). Prior research indicates that entrepreneurs often obtain financial resources from family and friends first, but soon require additional resources to finance the growth of their business (Gaston, 1989; Gompers, 1999).

The lack of capital and limited access to finance is a factor inhibiting entrepreneurship and influencing growth negatively, as it impedes the progress that comes from time application of resources (Chimucheka, 2014). 


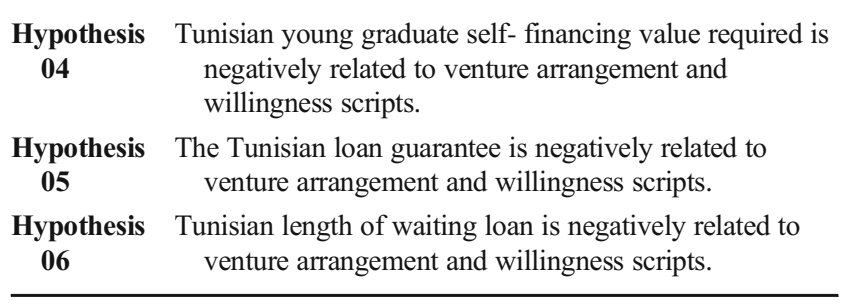

\section{Education system and NVCD scripts}

Education and training systems are integral components of the socioeconomic infrastructure that encourage individuals to be more entrepreneurial and hence, develop higher levels of venture scripts (Vesper \& Gartner, 1996). This system consists of two broad and interrelated sets of institutions: first, the education and training system, and second, the institutions that control the terms on which the owners of skills sell them in labor markets and how those markets are organized (Whitley, 1999a, b). Education seems important for stimulating entrepreneurship for several reasons (Davidsson \& Reynolds, 2005; Sánchez, 2010). First, education provides individuals with a sense of autonomy, independence, and self-confidence. Second, it makes people aware of alternative career choices. Third, education broadens the horizons of individuals, thereby making people better equipped to perceive opportunities. Finally, it provides knowledge that can be used by individuals to develop new entrepreneurial opportunities. Thus, it is likely that individuals from a country with higher quality educational systems (manifested by the population level of education) will perceive the environment to be more entrepreneurial munificent because they have better access to high-quality human resources (Begley et al., 2005), hence the high level of venture arrangement and willingness scripts. In this vein, Bowen and De Clercq (2008) have recently found that institutional arrangements, such as entrepreneurship and education, significantly influence society's allocation of entrepreneurial effort. Nevertheless, certain studies suggest that higher levels of education lead to better performance in entrepreneurial activities than when working as an employee (Evans \& Jovanovic, 1989). Moreover, a higher level of education can create a set of possible entrepreneurs attracted by the non-material advantages of entrepreneurship such as greater autonomy (Van Gelderen \& Jansen, 2006) and personal achievement (Apospori et al., 2005).

The Consortium for Entrepreneurship Education (2005) states that entrepreneurship education is not just about teaching someone to run a business. It is also about encouraging creative thinking and promoting a strong sense of self-worth and empowerment. Through entrepreneurship education, students learn how to create business, but they also learn a lot more. The core knowledge created via entrepreneurship education includes the following: the ability to recognize opportunities in one's life, the ability to pursue opportunities, by generating new ideas and found the needed recourses, and the ability to create and operate a new firm and the ability to think in a creative and critical manner. In addition to acquiring knowledge and skills in business, entrepreneurship education is mainly about the development of certain beliefs, values, and attitudes, with the aim to get students to really consider entrepreneurship as an attractive and valid alternative to paid employment or unemployment (Raposo \& Do Paço, 2011). On the other hand, education may be conducive to the focal individual's venture creation by enhancing his or her own human capital, that is, the knowledge structures related to entrepreneurship venture arrangements, willingness, and ability scripts. Empirically, it has been found that education influences the decision to be self-employed (Shane, 1994; Robinson \& Sexton, 1994). Education also improves the individual's willingness to start a new venture thanks to the increased self-efficacy (increasing belief in one's own orchestration capacity) that comes from possessing both specific technical and general social knowledge (Boyd \& Vozikis, 1994). These findings suggest that education enhances an individual's likelihood for venture creation, yielding higher levels of venture scripts pertaining to both entry (venture arrangements and willingness scripts) and doing (venture ability scripts).

Hypothesis
$\begin{gathered}\text { Th } \\ \text { Hypothesis }\end{gathered}$
$\begin{gathered}\text { 08 } \\ \text { venture arrangement willingness and ability scripts. }\end{gathered}$
$\begin{gathered}\text { Hypothesis } \\ \text { related to venture arrangement, willingness, and ability } \\ \text { scripts. }\end{gathered}$
$\begin{gathered}\text { Tunisian training soft skill level is positively related to the } \\ \text { venture willingness arrangement and ability scripts. }\end{gathered}$

\section{Trust relations and NVCD scripts}

Finally, the background institutions that influence the reliability of the parties engaged in economic transactions significantly influence the type of economic behavior that takes place within a country (Whitley, 1999a). Of particular relevance to entrepreneurship is a country's level of corruption, which is the extent to which public power is misused for private benefit in business transactions (Bowen \& De Clercq, 2008; de Soto, 2000). Corruption reflects inefficient, weak institutions governing trust relations (Djankov et al., 2002). In a country where corruption prevails, the rule of man gradually replaces the rule of law. The latter is predictable and facilitates entrepreneurial plans and actions; the former undermines the stability and reliability of these institutions (McMullen et al., 2008). It has been argued that there are benefits associated with corruption in economic development and 
entrepreneurship (Nye, 1967), such as reducing transaction costs through informal networking, especially in countries where formal institutions are not well developed (Lee et al., 2007). However, it is generally believed that returns from corruption are unlikely to be sustainable in the long run as demonstrated by the Asian economic crisis (Luo, 2002). Uncertainty induced by corruption may discourage potential entrepreneurs from starting a business (Aidis et al., 2008; Bowen \& De Clercq, 2008). Moreover, researchers have found that in former Soviet Union countries, higher levels of corruption discouraged business owners from expanding because of the risk that their firms would be expropriated by corrupt officials (Aidis \& Mickiewicz, 2006; Barkhatova, 2000). In an extensive analysis to ascertain why Western economies prosper while others languish, de Soto (2000) supported the work of Olson $(1996,1998)$ that identifies corruption as the key reason for dead capital due to the uncertainty that comes from lack of trust.

Researchers have also found that higher levels of corruption are associated with lower productivity and lower output growth across countries (Sachs et al., 1995). As follows, the main reason is that since corruption has been found to increase uncertainty and distrust in the business environment, they are likely to decrease the willingness of individuals to engage in entrepreneurial activities in the long run. Thus, we expect that the political factors, which affect the perception of the risk and the revenues of entrepreneurial activity, are important as well. The general rules of conduct and the political environment factors enable not only the discovery of entrepreneurial possibilities but also their transformation into enterprises and their further development (Cuervo, 2005). The government policies may affect the entrepreneurial dynamism of an individual country or region with either the introduction of specific policy measures or the creation of a general institutional structure that encourages entrepreneurial activity. There is a growing amount of literature, which examines the role of individual policy measures on entrepreneurship (Audretsch et al., 2007).

Barro (1996) analyzes the relationship between democracy and economic growth and finds a nonlinear relationship- democracy enhances growth at low levels of political freedom but hurts growth once some moderate level of political freedom exists.

Bureaucratic corruption and red tape can significantly increase business costs, and the time spent negotiating with corrupt officials makes products and services uncompetitive in the marketplace (Ahwireng-Obeng \& Piaray, 1999).

The term accompaniment means counseling, coaching, tutoring, sponsorship, or even mentoring. In fact, we retain that support is not limited to the field of entrepreneurship. It concerns as well education, vocational training, hospital setting, sport, legal, social, and socio-economic fields, etc. (Boulayoune, 2012). The services that interveners offer to entrepreneurs have four major deficiencies. The first problem concerns the financing programs that are available to entrepreneurs. The second concerns the cohesion in the general offer of services to entrepreneurs. Another shortcoming relates to insufficient training for entrepreneurs and interveners. Finally, the last problem relates to the monitoring of client companies. Thus, when discussing major gaps in funding, participants evoked the issue of lack of availability of venture capital, lack of flexibility in financing deals, and poor access to bank financing. They also mentioned the limited assistance for entrepreneurs who are 45 years old or more. It is also worth pointing out that counselors are facing the difficulty to keep updated due to the numerous and frequent changes in programs, which, in turn, has made Sfax face difficulties in the entrepreneurial field. The intervention of the accompanying structure, which is on the sharing of knowledge between the coach and the entrepreneur (cognitive dimension), was rejected. This calls into question the performance of Tunisian support structures (Paturel \& Maalel, 2016).

\begin{tabular}{ll}
\hline Hypothesis & Tunisian accompaniment and support level are negatively \\
$\mathbf{1 0}$ & related to venture arrangement and willingness scripts. \\
Hypothesis & Tunisian level of political instability is negatively related to \\
$\mathbf{1 1}$ & venture willingness scripts. \\
$\begin{array}{c}\text { Hypothesis } \\
\mathbf{1 2}\end{array}$ & $\begin{array}{c}\text { Tunisian level of corruption is negatively related to venture } \\
\text { willingness scripts. }\end{array}$ \\
\hline
\end{tabular}

\section{Conceptual framework}

Based on the arguments presented above, the conceptual model proposed in this study is presented in Fig. 1.

\section{Research methodology}

In this section, precisions will be supplied, first on the cognitive approach as a research tool used (3.1) and then, as a description of the used data (3.2).

\section{The cognitive approach as a research tool}

This study is of qualitative type. It uses, as a research tool, the cognitive approach that has been very little used until now in entrepreneurship. The use of cognitive mapping in the field of entrepreneurship is recent and dealt with by few empirical studies. It can lead to a better understanding of the individual cognitive universe (actors, entrepreneurs, managers); it is very important for the understanding of the weakness of the entrepreneurship formal institutions in micro-, meso-, and macrolevel in Tunisia. 


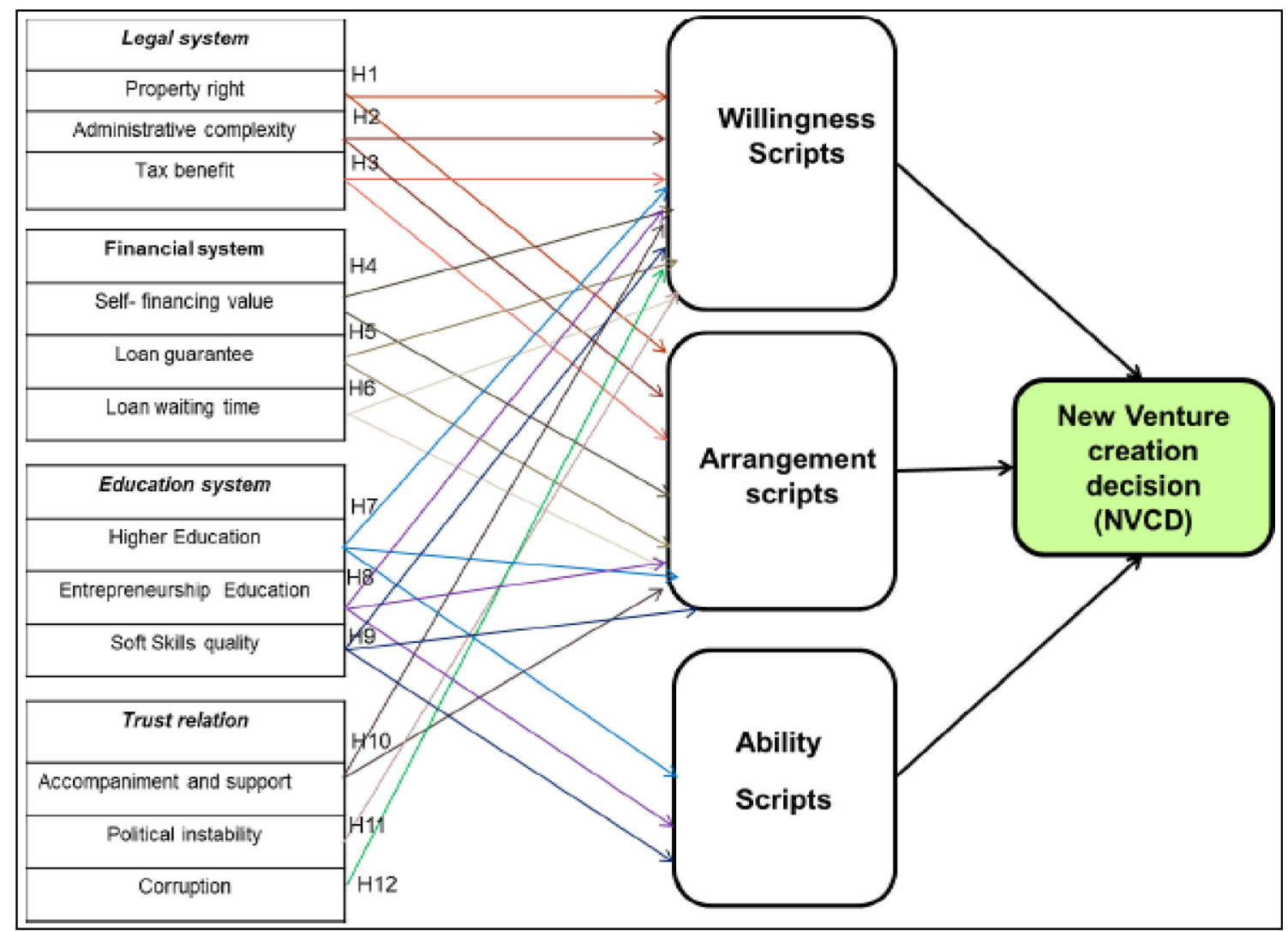

Fig. 1 Conceptual model of study

\section{Cognitive mapping: a tool for identifying the weakness of entrepreneurship formal institutions}

Since the publication of Axelrod (1976) work in political sciences, and especially, since the pioneering work of Bougon (1992) and Eden et al. (1973) in the organizational field, the researches carried out on the use of the cognitive mapping have undergone a considerable development. The use of cognitive maps in recent years in scientific research has grown (Franco \& Haase, 2009).

In this context, we use the cognitive map to give a collective view of the formal institutional weakness. The cognitive map is only a discursive representation (of a researcher) of a mental representation (of a subject) (Verstraete, 1996). Therefore, the researcher who uses this technique draws the map according to his own perception of reality. This dual representation drawn from the cognitive map will be expressed in Fig. 2.

\section{Construction phases of collective cognitive map}

The drawing of a collective map is made through the aggregation (assembly) of individual cognitive maps (Özesmi \& Özesmi, 2004). A cognitive map, whether collective or individual is composed of two essential elements: concepts and links. Concepts are considered variables and links explain the relationships between these variables. A concept can be influenced by other concepts according to their degree on the map. Thus, a concept (variable) is said to be important if it possesses numerous links with the other concepts (variable) on the map. For this reason, Webb and Weick (1979) suggests that the more a concept has entries or exits, the more it becomes important (Mouhli et al. 2019). Although the individual map is constructed from individual experiences, the collective cognitive map defines the group as all the individuals who compose it. Its construction is made through that of individual maps, followed by a stage of aggregation (addition) of these last ones (Özesmi \& Özesmi, 2004).

How small businesses fail in Tunisia The main objective of this research is to analyze the collective mental representation of the Tunisian nascent entrepreneurs concerning three formal institutions which have, according to the beliefs, an impact on their venture creation decision. To achieve this objective, a gait of three phases to build a collective cognitive map is proposed (Table 1). This gait relies on the alternation of two phases of conceptions: individual and collective (Fig. 3).

The construction and analysis of the collective cognitive map were made by the program (MIC-MAC). This program was chosen for its conviviality and its analytical skills. It allows identifying the explanatory variables from the cross-impact matrix (matrix structural analysis). It can also classify 
Fig. 2 Cognitive mapping: a representation of a representation Real

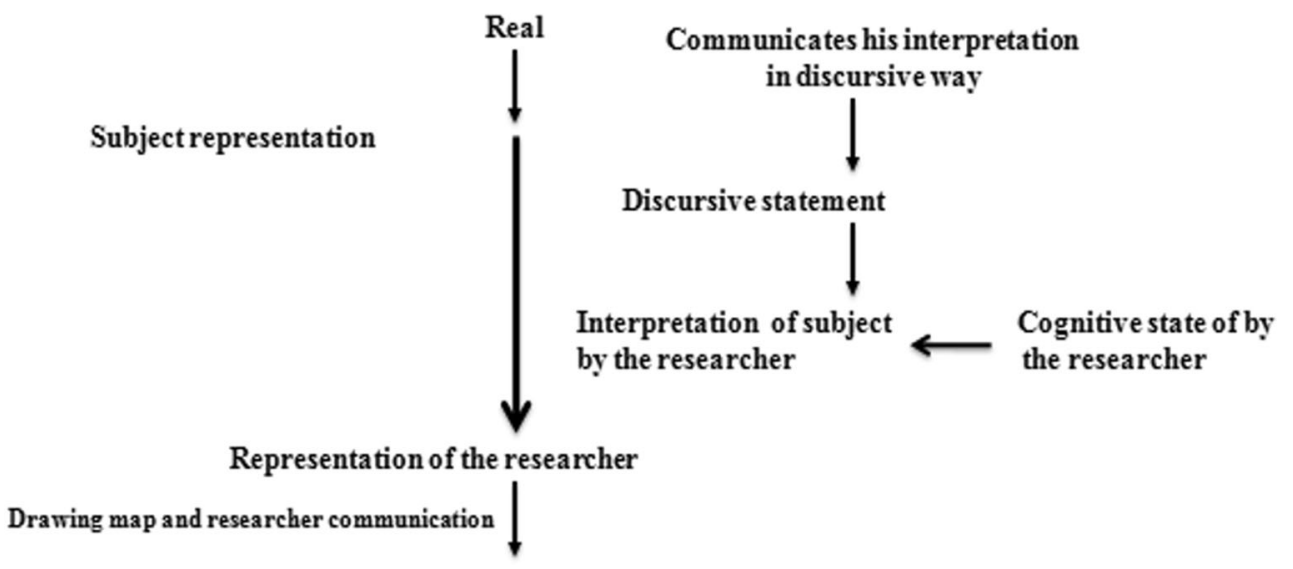

these variables according to their sensibility to the environment (dependence variables) and to their impact on other variables (motricity variables) (Fig. 4). The above program allows treating the information collected in the form of graphs and plans and configuring the mental representation of interviewees (Fig. 5).

\section{Data}

\section{Application and results}

Independently of its construction process, the cognitive map constitutes, in itself, an interesting product to be analyzed because it is a decisive tool to evaluate and provide alternatives to solve a problem. This average cognitive map of entrepreneurs is based on the structural analysis matrix, on the influence-dependence graph, and on the influence-dependence chart and the essential categories of entrepreneurial failure.

\section{The structural analysis matrix}

According to Benjamin (1999), structural analysis is a tool designed to link up ideas. It allows describing the system thanks to a matrix, which links up all its constitutive elements.

The method enables, by studying these relations, to underline the variables that are essential to the system's evolution. It has the advantage of stimulating reflection within the group and leading it to think about certain aspects, which are sometimes counterintuitive. It applies to the qualitative study of extremely different systems.

According to Smida et al. (2008), the structural analysis matrix allows identifying directly the key variables from the total, online and in column, weight influences between each couple of variables. It is used to measure the influence (lines sum) and the sensibility (columns sum) of each variable on the failure or success of the micro-enterprises.

This operation allowed not only to highlight the most influential and matrix dimensions and variables (Table 2) but also to rank them in order of "preponderance" and "dependence" from the influences/dependencies (Table 2).

The proportions submenu offers an additional table that complements the previous one. It proposes a classification of the variables according to their influence and their decreasing
Table 1 The three construction phases of "aggregate" cognitive map 1st step: Identification of concepts
(variables)

A. Gather the individual perception of the interviewees about the Tunisian formal institutional antecedents of venture creation decision.

$B$. To reveal through these interviews with different concepts, ideas, or examples related to this questioning.

$C$. The creation of a set (list) of concepts (variables) that will be used in the second step.

2nd stage: Analysis of the links between concepts

3rd step: The construction of the collective cognitive map
A. Each interviewee will evaluate the strength of the links between these concepts (the concepts developed during the first step) by constructing a cross-impact matrix for each of them, which contains only the common concepts.

A. Construct a collective matrix in which all-common concepts of respondents are found and "an aggregate causal intensity".

$B$. Construction of the collective map from the program (MIC-MAC) 
Fig. 3 The structural analysis matrix and its graphs

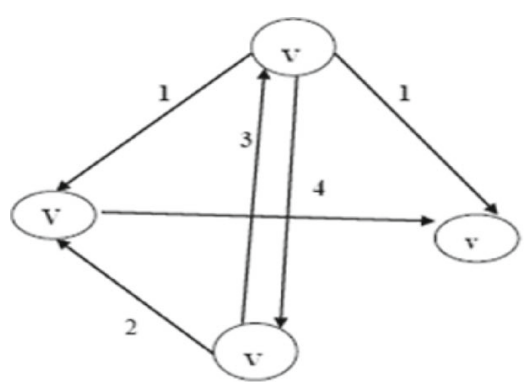

$$
\text { "A" = v } \begin{array}{c|cccc}
\text { v1 } & 0 & 0 & 0 & 3 \\
\text { v3 } & 1 & 0 & 4 & 0 \\
\text { v4 } & 1 & 0 & 0 & 0 \\
1 & 2 & 0 & 0
\end{array}
$$

\begin{tabular}{|l|l|l|l|c|c|}
\hline \multicolumn{2}{|l|}{} & Total \\
\hline (of the i-th line) & 3513 & 12 & (of the i-the line) & 3513 & 12 \\
\hline $\begin{array}{l}\text { Addiction ( of the j-th } \\
\text { column) }\end{array}$ & 3243 & 12 & Addiction(of the j-the column) & 3243 & 12 \\
\hline
\end{tabular}

dependency (direct and indirect) (Table 3). Thanks to the Micmac Prospective program, the variables are then, ranked by decreasing rank of influence and direct and indirect dependence. All of the structural analysis matrices above have been established only from direct relationships between the variables. However, it is clear that a variable can also influence the other variables indirectly, through another variable.

\section{The graph of influences}

The cognitive map can take the form of an influence graph (Fig. 7). Based on this representation and viewing the complexity of the interrelated network of variables, it is very difficult to give an appropriate interpretation. However, this does not exclude the possibility of identifying the most important factors of the phenomenon studied. The analysis of the average map clearly identifies two categories of factors. In the first category, sensitive factors, also known as influencing factors or "consequences," are influenced by other factors (this category is grouped in the center of the map). These factors are considered very important only when several direct links are included. Whereas in the second category, there are the motor factors, which are also called factors influencing or "explanation," which exert a direct influence on many others. These factors are considered very important only when several direct links are made. "Average" cognitive map of entrepreneurs is in the form of the graph of influence.

From Fig. 7, it can be seen the direct influences (based on $18 \%$ ) that can exist between entrepreneurial culture and the ability script. This means that young graduates can develop certain skills such as coaching, preparing a business plan through entrepreneurship training in Tunisian universities. Then the more the training develops and improves in our university, the more entrepreneurial skills develop among the young graduates and consequently, help them widely make the right decisions. In this sense, the university can make partnerships with civil society's enterprises; an entrepreneur has a success story if he completes the theoretical ones by the practice. A strong potential interdependent also arises between the administrative procedures and the script arrangement that is entered into the decision-making process.

In this last graph, we concentrate mainly on revealing the interaction relation that can exist between the three scripts (arrangement, willingness, and abilities). It is a relationship
Fig. 4 Classification of variables, according to the motricity and dependency criteria

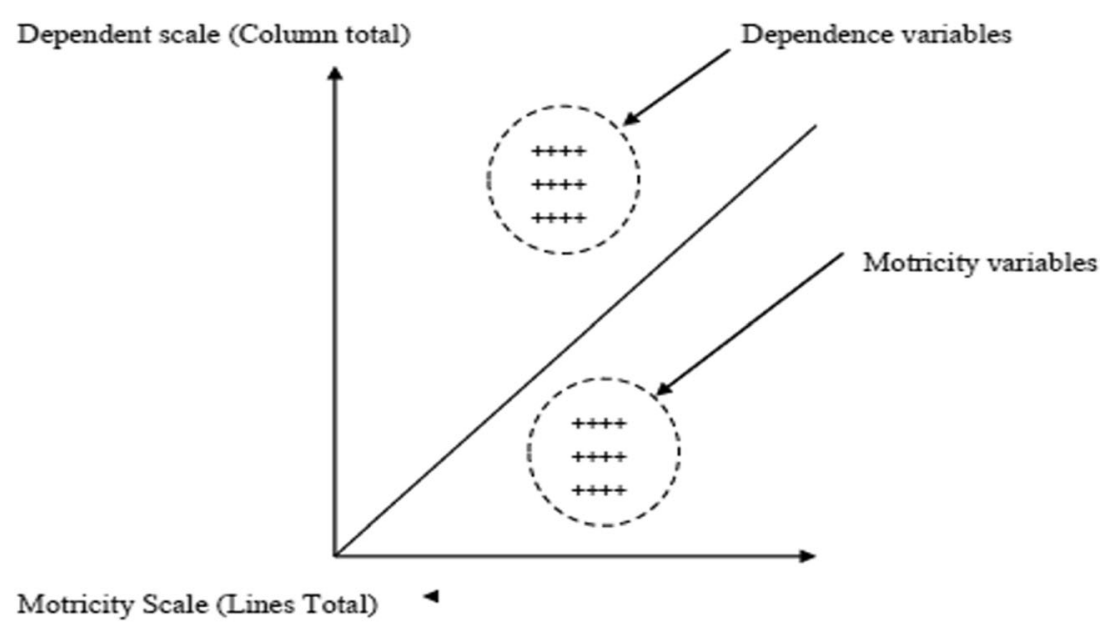



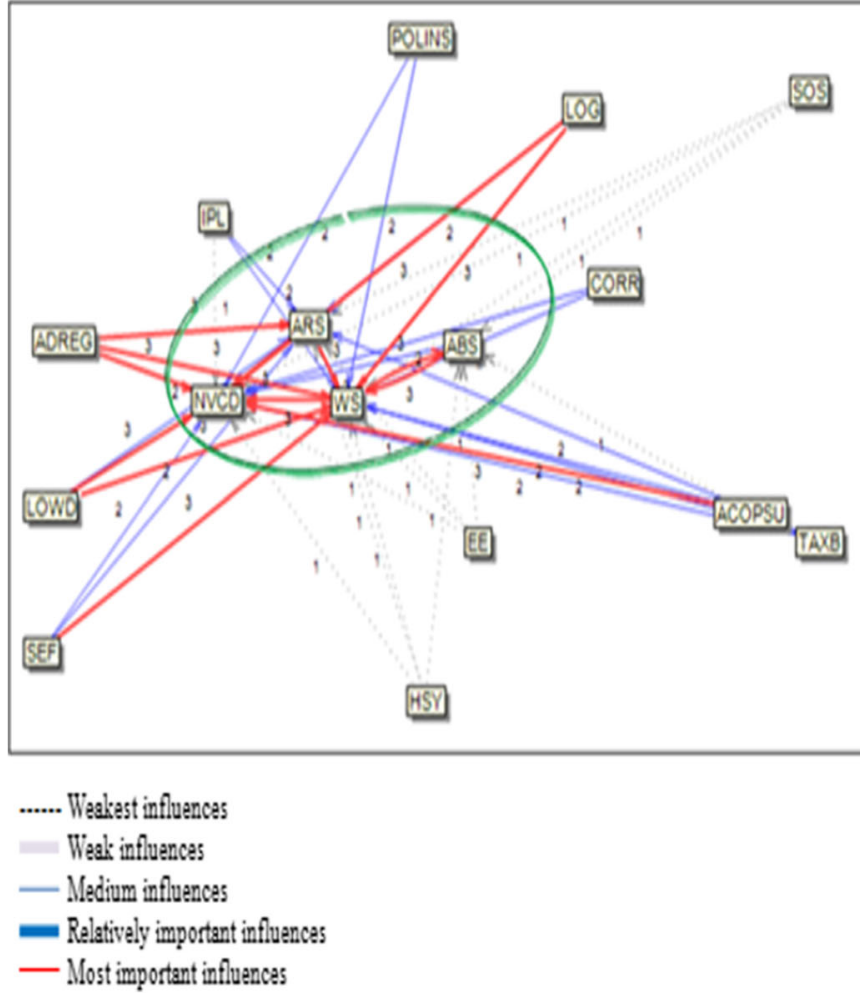

Fig. 5 Graph of direct influences

of interdependence; the change that undergoes on one of these scripts can influence the other script and vice versa. For example, if the arrangement script is expanded, it positively influences the willingness script. This confirms the dynamic,

Table 2 This table is used to fill in the row and column sums of the direct influences

\begin{tabular}{llll}
\hline$N^{\circ}$ & Variable & Total lines & Total columns \\
\hline 1 & New venture creation decision & 0 & 32 \\
2 & Arrangement scripts & 6 & 16 \\
3 & Willingness scripts & 6 & 31 \\
4 & Ability scripts & 5 & 7 \\
5 & Self-financing & 7 & 0 \\
6 & Loan guarantee & 8 & 0 \\
7 & Loan waiting duration & 8 & 0 \\
8 & Administrative regulation & 9 & 0 \\
9 & Intellectual property law & 5 & 0 \\
10 & Tax benefit & 6 & 0 \\
11 & Higher study years & 4 & 0 \\
12 & Entrepreneurship education & 4 & 0 \\
13 & Soft skills & 4 & 0 \\
14 & Accompaniment and support & 6 & 0 \\
15 & Political instability & 4 & 0 \\
16 & Corruption & 4 & 0 \\
& Total & 86 & 86 \\
\hline
\end{tabular}
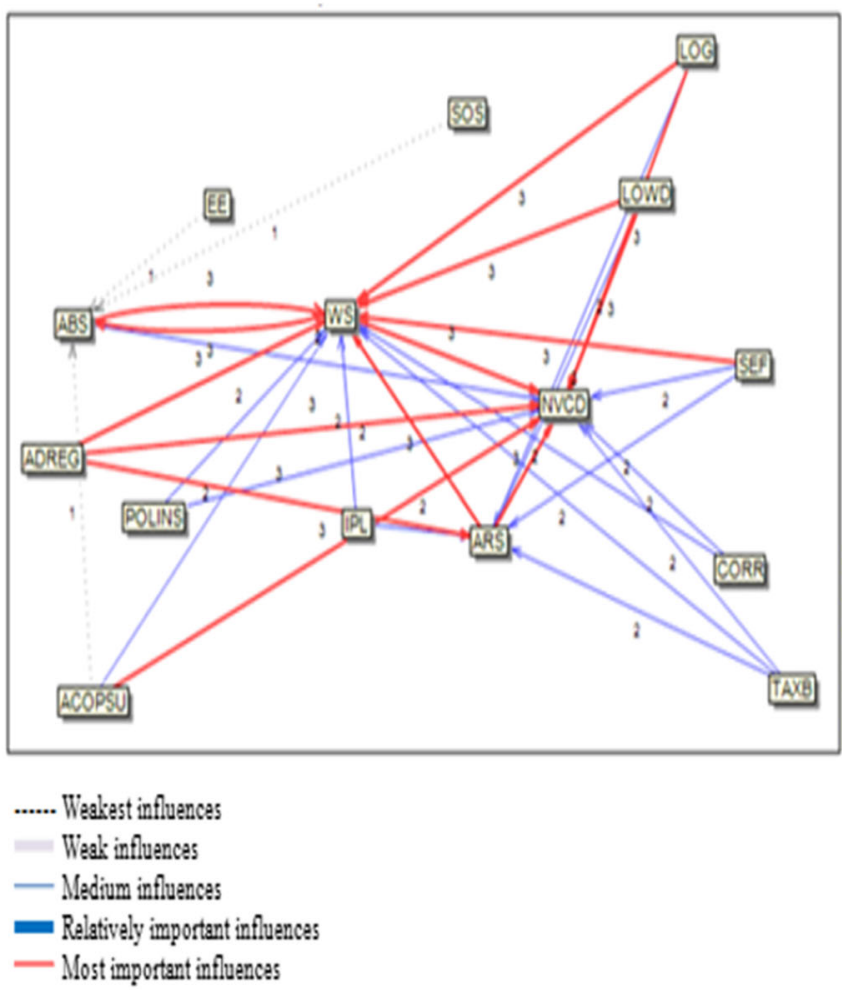

situational aspect that characterizes the scripting process and the interdependence aspect of this process with the decisionmaking process for the venture creation decision.

The previous graphs reveal many important points. Firstly, it shows the main formal institutional antecedents that form the cognitive universe of Tunisian nascent entrepreneurs. Secondly, it presents the value of influence and interdependencies (weak, medium, strong) that they consider between these formal institutional antecedents (administration, financial system, educational system, etc.) and the three essential scripts (arrangement, willingness, and ability scripts) for the entrepreneur cognition. In addition, it confirms the link between the entrepreneurial scripts as a mediator and the NVCD. This analysis may give the government the opportunity to act more effectively in the process of decision-making of future entrepreneurs by the implementation of an entrepreneurship policy axed in the development of these formal institutional antecedents in aims to improve its role in the Tunisian young graduate representation vis-a-vis the decision to venture creation decision.

\section{The influence dependence plan}

The plan of influences/dependencies is a graph where each concept/variable is projected according to its global influence and its dependence on the others (Figs. 6 and 7). The positioning of the point cloud of the set of variables on the plan of influences/dependencies resulting from the structural analysis 
Table 3 Classification of variables (factors) according to their motricity and sensitivity

\begin{tabular}{|c|c|c|c|c|c|c|c|c|}
\hline Rank & Entitled & Direct influence & Entitled & Direct dependence & Entitled & Indirect influence & Entitled & Indirect dependence \\
\hline 1 & ADREG & 1046 & NVCD & 3720 & ADREG & 1126 & NVCD & 4470 \\
\hline 2 & LOG & 930 & WS & 3604 & SEF & 921 & WS & 3174 \\
\hline 3 & LOWD & 930 & ARS & 1860 & LOG & 921 & ABS & 2354 \\
\hline 4 & SEF & 813 & ABS & 813 & LOWD & 921 & ARS & 0 \\
\hline 5 & ARS & 697 & SEF & 0 & IPL & 750 & SEF & 0 \\
\hline 6 & WS & 697 & LOG & 0 & TAXB & 750 & LOG & 0 \\
\hline 7 & TAXB & 697 & LOWD & 0 & WS & 614 & LOWD & 0 \\
\hline 8 & ACOPSU & 697 & ADREG & 0 & HSY & 580 & ADREG & 0 \\
\hline 9 & ABS & 581 & IPL & 0 & $\mathrm{EE}$ & 580 & IPL & 0 \\
\hline 10 & IPL & 581 & TAXB & 0 & SOS & 580 & TAXB & 0 \\
\hline 11 & HSY & 465 & HSY & 0 & ACOPSU & 546 & HSY & 0 \\
\hline 12 & $\mathrm{EE}$ & 465 & $\mathrm{EE}$ & 0 & ARS & 511 & $\mathrm{EE}$ & 0 \\
\hline 13 & SOS & 465 & SOS & 0 & ABS & 511 & SOS & 0 \\
\hline 14 & POLINS & 465 & ACOPSU & 0 & POLINS & 341 & ACOPSU & 0 \\
\hline 15 & CORR & 465 & POLINS & 0 & CORR & 341 & POLINS & 0 \\
\hline 16 & NVCD & 0 & CORR & 0 & NVCD & 0 & CORR & 0 \\
\hline 1 & ADREG & 1046 & NVCD & 3720 & ADREG & 1126 & NVCD & 4470 \\
\hline 2 & LOG & 930 & WS & 3604 & SEF & 921 & WS & 3174 \\
\hline
\end{tabular}

makes it possible to distinguish four groups of variables (motor, relay, excluded, and results or dependent) allowing a perfect readability of the phenomenon of venture creation decision. Each group is distinguished from the others by the particular role these variables can play in the venture creation decision process (Fig. 8).

\section{Zone A: "influent" variables}

These are variables, which have a high index of motricity (influence) and a low index of dependence. They are altogether very influential and less dependent on the rest of the

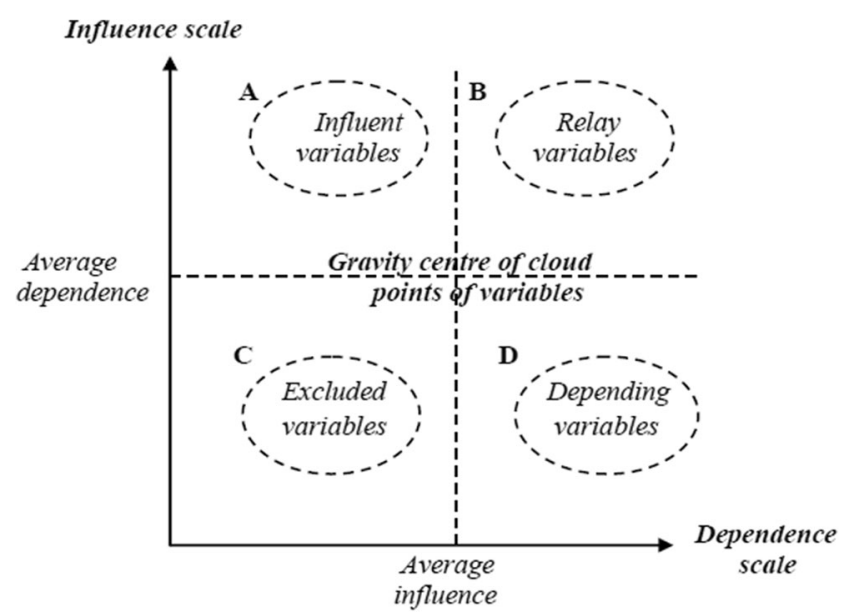

Fig. 6 Classification of variables, according to the motricity and dependency criteria variables. The motrice influent variables are its most important elements because they can act on the system, depending on how much we can control them as a key factor of either moving or inertia. These variables are settled explanations because they are the elements in the planning of the venture creation decision process.

Zone A includes the most influential variables such as selffinancing (SEF, LOG, LOWD, and TAXB); in particular, without the contribution of the nascent entrepreneur in an amount equal to $5 \%$ of the value of the project, it will not have the necessary loan for the venture creation.

The majority of emerging entrepreneur interviews, since entrepreneurs in this phase are only young graduates, who do not have the necessary amount and depend in most cases on their family or friends, regarded this procedure as the major obstacle. The second variable is administrative regulations (ADREG), which are the variable number 4 that influences the decision of Tunisian nascent entrepreneurs. A large number of interviewees say that they have suffered a lot from preparing the necessary documents to get started. Some of them say that they arrive at times when they seriously think to reject the idea of embarking on entrepreneurship. It explains this is explained by the bureaucracy and the complexity as well as the nepotism (corruption feature), which sometimes affect the Tunisian administration that was a constraint in their decision-making process or when it must be a lever and a true supporter for these young graduates in this articulated stage. 

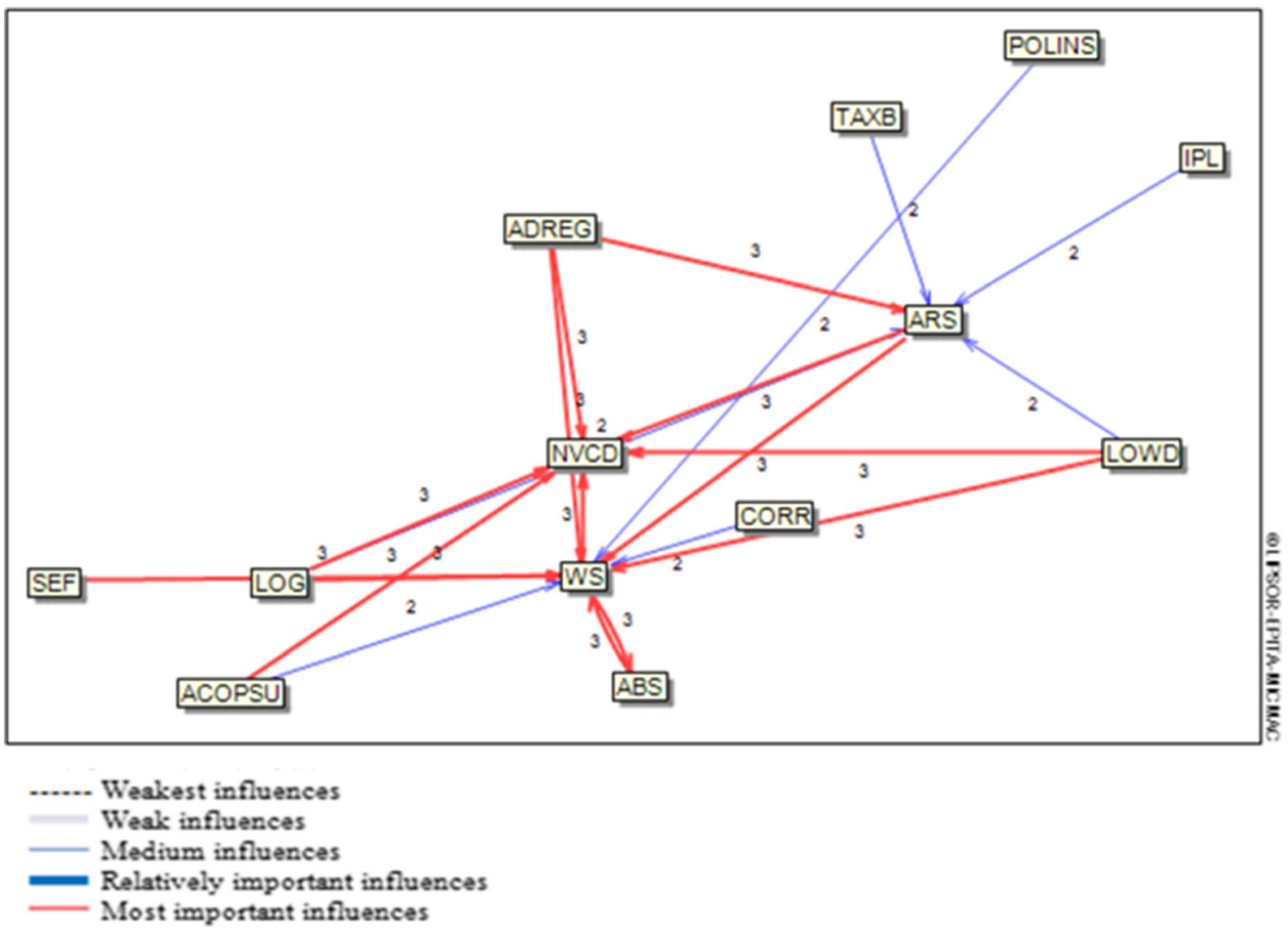

Fig. 7 The interaction relation that can exist between the three scripts (arrangement, willingness, and abilities)

Plan des influences / dépendances directes

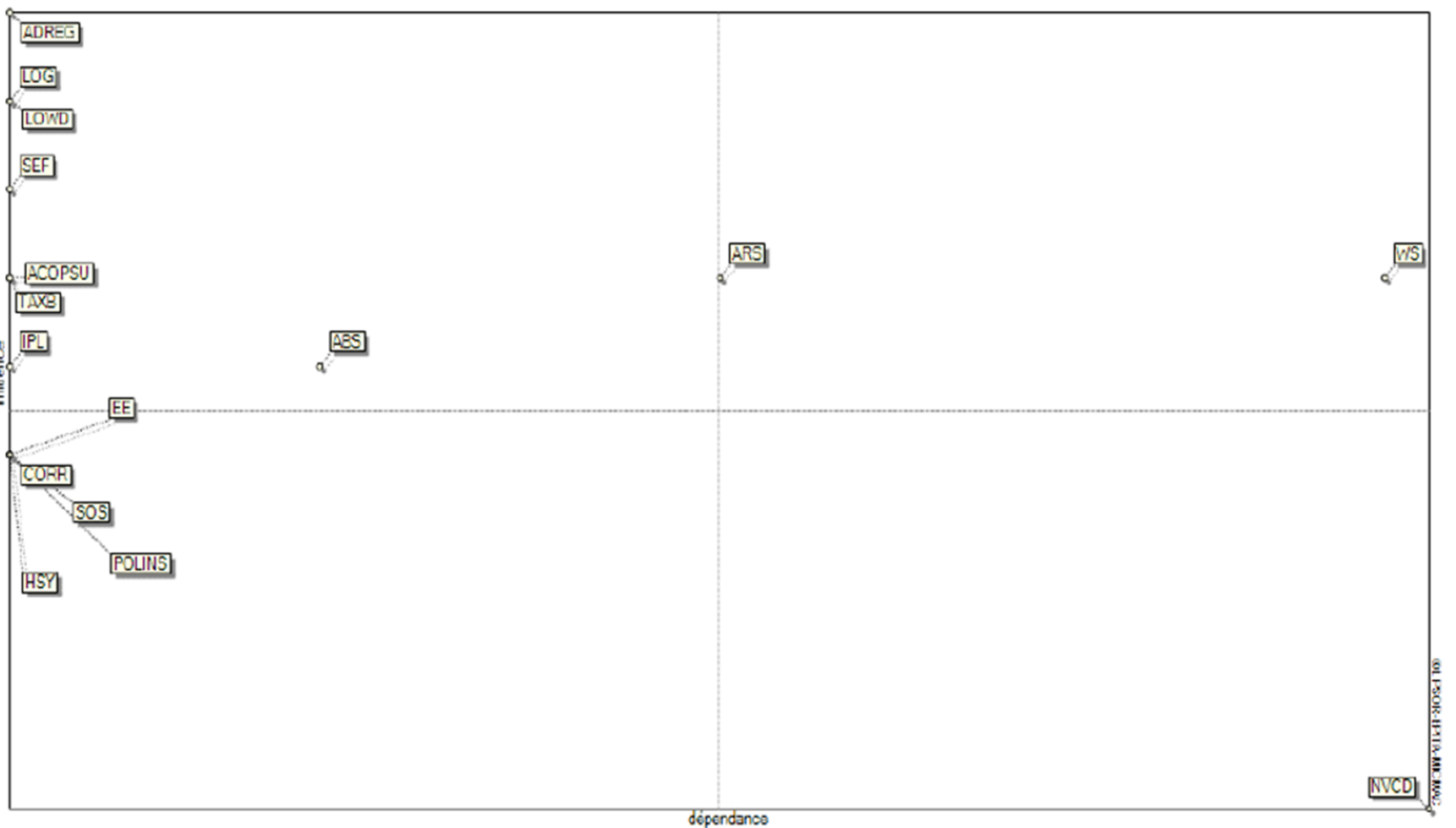

Fig. 8 Plan of direct influence and direct dependence 


\section{Zone B: "relay" variables}

Intermediate or relay variables are at the same time very influential and very dependent (highly influenced and highly dependent). These variables are situated in the northeast frame of the chart. They are, by nature, factors of instability because any effect on them will have an effect on the other and on themselves. They also constitute the turning point between success and failure. Looking closely at Fig. 7, which synthesizes the influence-dependence plan, these variables are situated on the top right. These variables, which are related to the venture creation decision, are first of all the arrangement scripts, which represent the input to the decision. This involves knowledge about access to public resources such as banks (BTS, BFPME), knowledge relating to the contact of the administration, which provides the necessary documents for the launching of a project (agreement, license, contracts).

Interviewed entrepreneurs do not hide their dissatisfaction with the Tunisian administration, which is considered slow. They suffer from bureaucracy and even corruption. This hinders and complicates their entry and weakens the second relay variable in this plan, which is the willingness script to embark on entrepreneurship.

\section{Zone C: "excluded" variables}

The excluded or autonomous variables are those, which have, at the same time, weak influence and little dependence. These variables are positioned in the southwest casing and appear quite out of line with the system because they permit neither to stop a major evolution undergone by the system nor to really take benefit of it. Their development is relatively autonomous: they have no serious influence on NVCD of Tunisian nascent entrepreneurs. Considering the influence-dependence plan, we can single out certain excluded such as HSY, EE, and SOS. Tunisian nascent entrepreneurs, after the revolution, are not based on these variables when they decide to start, since these antecedents have few positive influences and were not perceived as stimulating factors of entrepreneurship. Many other variables are indicated by some nascent entrepreneurs like strike, business, climate informal trade, and economic growth. Faced with this delicate situation with a large proportion of Tunisian nascent entrepreneurs report that they perceive a high-risk rate and uncertainty at the time of the decision. They also record a fuzzy look, which is disturbing to the future of its newly created organizations.

\section{Zone D: "depending" variables}

Results or depending variables, or rather, the dependent variable, located in the southeast frame of the chart, are a few influential and very dependent NVCD. Thus, they are particularly sensitive to the evolution of matrices and/or relay variables. They are exit variables from the system. These variables, which can be explained by their acting on the influent and relay variables, are conditioned by too many factors. The decision to create a new organization (NVCD) depends on the influence of the zone A variables, on the zone B variables, project financing system, administration procedure, which are antecedents belonging to zone A having a direct influence on entrepreneurial scripts (ARS, WS) that are arrangement scripts, willingness scripts, and ability scripts that belong to zone B variables. Zone A developed (positive influence) or weakened (negative influence) the variables of zone B and consequently developed or inhibited the variable of zone $\mathrm{D}$, which is the decision to create a new organization in a given territory.

In reality, there are other kinds of antecedents that nascent entrepreneur expressed on explaining their NVCD like opportunity, social antecedents (family, social capital, friends, etc.), psychological antecedents (to be responsible, risk-oriented, self-realizing, passionate, independent, etc.), and professional antecedents (experience, low salary, etc.). So it is important to know the advantage when having an efficient and transparent administration that simplifies entry regulations, a strong financial system that speedy offers the young graduates the necessary funding to launch their projects, a developed education system that offers quality entrepreneurial training, which is both a stable and strong political system. All these formal institutional antecedents can together form a platform of entrepreneurship that supports young people and essentially young graduates to move from a wage culture to an entrepreneurial culture and perceive entrepreneurship as a true alternative career. Many of the formal institutional antecedents like political instability, higher education, entrepreneurship education, and soft skills are found in zone $\mathrm{C}$ as (excluded variable); this clearly demonstrates the weakness of the Tunisian formal institutional environment since these variables in principle must be found in zone A as influencing variables. The Tunisian government must improve security, reassure democracy, and establish a media and an administration that greatly serve the entrepreneurial activity mainly among young graduates. The media here has a great role to play in raising young people's awareness of entrepreneurship and recognizing the mechanisms and advantages that the Tunisian government offers in this field to promote the culture and especially the entrepreneurial cognition of the latter and Leads them to the entrepreneurial career.

\section{The formals institutional weakness and associated factors}

For the identification of the major formal institutional antecedents of the decision to create a new organization at the level of the Tunisian nascent entrepreneurs, cognitive mapping allowed us to group the variables into several categories/ 
dimensions, where each category is in reality only one sub-"patatoids" set of key factors. This grouping of factors/ variables in the form of "patatoids" is done according to their proximity in the plan of influences/dependencies and their semantic approximation. Each "patatoid" has a title expressing the meaning of the variables concerned. Their application leads to the construction of four dimensions/categories of NVCD process weakness levels (Table 4):

- The dimension related to entrepreneur

- The dimension related to NVCD process

- The dimension related to formal institutional system

- The dimension related to entrepreneurial cognition scripts

\section{Discussion and conclusions}

The objective of this research is to determine the role of the institutionalization of Tunisia (the legal system, the financial system, the educational system) in the decision to create a new organization among Tunisian nascent entrepreneurs (young graduates). To do this, a cognitive approach is applied using the structural analysis method as a tool for structuring ideas and collective reflections. The use of this approach in the field of entrepreneurship has been the subject of few empirical studies. It leads to a better understanding of the cognitive universe of individuals (actors, coaches, managers, entrepreneurs, etc.) and it is important in this study's context in identifying and analyzing the influence of formal institutional antecedents on the cognition of Tunisian nascent entrepreneurs and consequently on their decision. The experimentation of this last one on 120 born entrepreneurs incubating in the

Table 4 Formals institutional antecedents' weakness level and associated factors

\footnotetext{
Micro-level (entrepreneur)*_Higher education diploma

- Entrepreneurship education

- Soft skills quality

- Self-financing

Meso-level (NVCD process)* _-Administrative regulations

-Loan guarantee

- Loan waiting duration

- Tax benefits

Macro-level (national)* - Accompaniment and support

- Political instability

- Corruption

Entrepreneurial cognition**_Novices arrangements scripts

- Novices willingness scripts

- Novices ability scripts
}

Note: *Dimension of matrices variables

Note: **Dimension of dependency variables nurseries allowed presenting, in the form of a collective map, the formal institutional antecedents that seem to affect their decisions to become entrepreneurs through their NVCD scripts.

\section{Summary of results}

The determination of individual visions, their pooling in the form of aggregation, and their in-depth analysis using the Mic-Mac program are almost crucial steps in a successful approach to charting a common vision of reality.

The proposed analysis of the average cognitive map of Tunisian formal institutional antecedents of the decision to create a new organization using the Mic-Mac program revealed certain characteristics that it would have been difficult to detect otherwise. This analysis is based on the following three aspects: the structural analysis matrix (allows to measure the influence or the sensitivity of each formal institutional antecedent, scripts, and the NVCD), the graph of the influences (makes it possible to identify the influencing factors and the Factors influenced), and, finally, the plan of influences/ dependencies (allows to group the variables into four groups allowing a perfect readability of the decision phenomenon of creation of a new organization). In sum, the study of these three aspects made it possible to highlight the NVCD process at the level of Tunisian nascent entrepreneurs and their associated formal institutional antecedents. These dimensions were distinguished according to the proximity of variables/ concepts in the plan of influences/dependencies and their semantic approximation.

The results obtained from this analysis verify the initial hypothesis proposed: why the Tunisian formal institutional antecedents do not play their natural role until now in the development of the cognition of Tunisian nascent entrepreneurs? Sometimes it is a constraint for who decide to become entrepreneurs by a weak financial system (loan value, selffinancing, time duration), an inadequate educational system (higher education, entrepreneurship training, soft skills, etc.), the unprecedented legal system (bureaucracy, complexity, tax), and a weak trust relation (political instability, corruption). Tunisian nascent entrepreneurs represent badly the current state of formal institutional antecedents, which, in general, influence negatively their entrepreneurial cognition because it complicates and retards their decisions, who consider it a very risky decision with a high level of uncertainty and ambiguity.

These results inform us, first of all, about the close relationship between the formal institutional environment and the entrepreneurs' cognition and, secondly, confirm the importance of the institutional environment in the decision to create a new organization. The next is to develop the financial system, the educational system, the administration, the political 
situation, the security, and the business climates, which become basic factors in the development of young graduate's entrepreneurial cognition of future entrepreneurs. It appears that this confirms the seminal research based on the relationship between formal institutional environment and entrepreneurial activity. Stenholm et al. (2013) have suggested that the regulatory framework tends to have a stronger effect on entrepreneurial activity than informal institutions. However, Stephen et al.'s (2005) cross-country study has demonstrated that legal institutions have an impact on the countries' level of entrepreneurship. Schmitz et al.'s (2009) study is based on the World Bank Group Entrepreneurship Survey data; it has further shown that entrepreneurial-friendly countries tend to have high business start-up rates matched with a stable political environment, modern business registration systems, reduced bureaucratic requirements, and simplified business laws. Nystrom (2009) supports this line of argument with a crosscountry study founding that a smaller government sector, well-developed legal structure and security of property rights, and less strict regulation of credit, labor, and business are positively related to entrepreneurial activity. Moreover, Grilo and Thurik (2005) have demonstrated that the majority of the population of the $25 \mathrm{EU}$ member states of the time and the USA perceives administrative and bureaucratic complexities as a formal start-up barrier, exerting a negative impact on nascent and actual entrepreneurship levels. Lim and Schoenung's (2010) research on formal institutional influences in entrepreneurial cognitive and decision-making processes has shown that individuals in countries with less-complex regulatory regimes and more property rights protection generally show higher levels of venture arrangements and willingness scripts. To this, the study of Bosma and Schutjens (2011) has added that the identified positive relation between strong entrepreneurial attitudes and subsequent entrepreneurial activity is not straightforward. There are national formal institutional [...] forces at play, which at the individual level reinforce or deter the decision to indeed start a business.

As a result of this contribution, the most important question to ask is the identification of the privileges, recommendations, implications, and actions that can be drawn from the study of the influence of Tunisian formal institutional antecedents on the entrepreneurial cognition of nascent entrepreneur (young graduates) that drive their decision to become an entrepreneur. However, it should be noted, at this stage, that the core of this study lies in the methodological approach used in the construction and analysis of the map and not only in terms of the results stated. This contribution revealed that structural analysis, as a tool for building the cognitive map, could help the Tunisian government and support structures to evaluate, identify, and analyze the weaknesses of the national entrepreneurship mechanisms. Thus, they have put in place effective policy to develop these institutions (banks, administrations, universities, etc.), for becoming more visible, their interventions more effective, and especially must be more connected with the future entrepreneurs mainly young graduates.

Other advantages may arise from the lessons that can be drawn from the study of the Tunisian formal institutional antecedents in relation to the decision to become entrepreneurial, firstly the cognitive approach, which can be used mainly for the teaching of entrepreneurship. Secondly, the development of cognitive mapping for the venture creation decision can be used to transform beginner entrepreneurial scripts (arrangement, willingness, and ability scripts) of Tunisian students (potential entrepreneurs) into more expert entrepreneurial scripts. Thirdly, it is important to use this expertise in decision-making and to deal with risks, uncertainties, and how to transform them into an opportunity.

This paper offers some important contributions to the literature. First, it provides a methodological contribution to the elaboration and analysis of the "average" cognitive map in the field of entrepreneurship and confirms its usefulness (Cossette, 2002; Eden \& Ackerman, 1998). It is essential in situations where the analysis of its structure and its continuum is important to understand, like the formal institutional antecedents of the venture creation decision. Next, it offers a new technique for the construction of cognitive maps, namely the Mic-Mac program (Bertrand et al., 2001). Finally, although formal institutional antecedents are discussed by many authors, there is little data available in the literature concerning the role of these antecedents in the Tunisian context. As a result, this chapter provides a detailed and relevant analysis of these formal institutional antecedents and how it is viewed by the Tunisian nascent entrepreneur and how it is related to their decision to become an entrepreneur. In fact, the formal institutional antecedents of the decision to become entrepreneurs are still a phenomenon that is too little addressed in the literature on entrepreneurship and the emphasis has been placed on other antecedents (psychological, social, and economic) of the other phases, essentially the post-creation phase. In this sense, Kibler et al. (2012) have said that this growing body of research has sought to respond to the over-dominance of studies on existing entrepreneurs or firms, in other words, to the lack of knowledge of how to emerge. Yet the decision to become an entrepreneur, even if it is almost always difficult to count all these roots, can in fact become a tool for discovering new antecedents, essentially formal institutional antecedents. It is an ambitious field that can occupy the very essence of entrepreneurship. Thus, its analysis could lead to original knowledge and targeted strategic actions to anticipate institutional constraints that complicate and delay the decisions about becoming an entrepreneur. Regrettably, the representation of the Tunisian nascent entrepreneurs is negative toward the formal institutional antecedents. It leads us to some recommendations for decision-makers, consultants, and trainers for enhancing this reality. It is clear today that this field of 
investigation could offer prospects for future research in order to be able to evaluate the degree of correlation between the programs proposed by the government and the needs of the beneficiaries. Attempts to mitigate, or eliminate negative impacts, can be greatly useful for the establishment of performance indicators, guaranteed the design of a more developed and more efficient Tunisian entrepreneurial policy.

Abbreviations $\quad C D C$, deposit and consignment fund; ILO, International Labor Organization; $O N E Q$, National Observatory of Employment and Qualifications; $V C D$, venture creation decision

Acknowledgements The authors would like to acknowledge Professor Boujelbene Younes for his help, support, and motivation.

Availability of data and materials The dataset used for this study is available from the corresponding author on reasonable.

Author contribution All the authors have read and approved the final manuscript. Both first and second authors have contributed the major part, while the third has contributed comparatively lesser.

\section{Declarations}

Competing interests The authors declare no competing interests.

Open Access This article is licensed under a Creative Commons Attribution 4.0 International License, which permits use, sharing, adaptation, distribution and reproduction in any medium or format, as long as you give appropriate credit to the original author(s) and the source, provide a link to the Creative Commons licence, and indicate if changes were made. The images or other third party material in this article are included in the article's Creative Commons licence, unless indicated otherwise in a credit line to the material. If material is not included in the article's Creative Commons licence and your intended use is not permitted by statutory regulation or exceeds the permitted use, you will need to obtain permission directly from the copyright holder. To view a copy of this licence, visit http://creativecommons.org/licenses/by/4.0/.

\section{References}

Acs, Z., Desai, S., \& Hessels, J. (2008). Entrepreneurship, economic development and institutions. Small Business Economics, 31, 219 234 Google scholar.

Ahwireng-Obeng, F., \& Piaray, D. (1999). Institutional obstacles to South African entrepreneurship. South African Journal of Business Management, 30(3), 78-85.

Aidis, R., \& Mickiewicz, T. (2006). Entrepreneurs, expectations and business expansion: Lessons from Lithuania. Europe-Asia Studies, $58(6)$.

Aidis, R., Estrin, S., \& Mickiewicz, T. (2008). Institutions and entrepreneurship development in Russia: A comparative perspective. Journal of Business Venturing, 23(6), 656-672.

Albert, A. P., \& Large, W. A. (2002). Activation of store- operated channels by noradrenaline via protein kinase $\mathrm{C}$ in rabbit portal vein myocytes. The Journal of Physiology, 544(1), 113-125.

Apospori, E., Papalexandris, N., \& Galanaki, E. (2005). Entrepreneurial and professional CEOs. Leadership \& Organization Development Journal.
Audretsch, D. B. (2007). The entrepreneurial society. University Press on Demand.

Axelrod, R. (1976). The cognitive mapping approach to decision making. Structure of Decision, 221-250.

Baker, T., \& Nelson, R. E. (2005). Creating something from nothing: Resource construction through entrepreneurial bricolage. Administrative Science Quarterly, 50(3), 329-366.

Barkhatova, N. (2000). Russian small business, authorities and the state. Europe-Asia Studies, 52(4), 657-676.

Barro, R. J. (1996). Democracy and growth. Journal of Economic Growth, 1(1), 1-27.

Baumol, W. J. (1990). Entrepreneurship: Productive, unproductive and destructive. Journal of Political Economy, 98(5), 893-921 Google scholar.

Begley, T. M., Tan, W.-L., \& Schoch, H. (2005). Politico-economic factors associated with interest in starting a business: A multi-country study. Entrepreneurship Theory and Practice, 29(1), 35-55 Google scholar.

Benjamin, W. (1999). The arcades project. Harvard University Press.

Bertrand, M., et al. (2001). Should the angiotensin II antagonists be discontinued before surgery? Anesthesia \& Analgesia, 92(1), 26-30.

Bird, B. J. (1992). The operation of intentions in time: The emergence of the new venture. Entrepreneurship Theory and Practice, 17(1), 1120.

Bosma, N., \& Schutjens, V. (2009). Mapping entrepreneurial activity and entrepreneurial attitudes in European regions. International Journal of Entrepreneurship and Small Business, 7(2), 191-213.

Bosma, N., \& Schutjens, V. (2011). Understanding regional variation in entrepreneurial activity and entrepreneurial attitude in Europe. The Annals of Regional Science, 47(3), 711-742 Google scholar.

Bougon, M. G. (1992). Congregate cognitive maps: a unified dynamic theory of organization and strategy. Journal of Management Studies, 29(3), 369-387.

Boulayoune, A. (2012). Social assistance: Putting things into perspective. Informations Sociales, (1), 8-11 Google scholar.

Bowen, H. P., \& De Clercq, D. (2008). Institutional context and the allocation of entrepreneurial effort. Journal of International Business Studies, 39(4), 747-767.

Boyd, N. G., \& Vozikis, G. S. (1994). The influence of self-efficacy on the development of entrepreneurial intentions and actions. Entrepreneurship Theory and Practice, 18(4), 63-77.

Bruton, G. D., Ahlstrom, D., \& Li, H.-L. (2010). Institutional theory and entrepreneurship: where are we now and where do we need to move in the future? Entrepreneurship Theory and Practice, 34(3), 421440.

Busenitz, L. W., \& Lau, C.-M. (1996). A cross-cultural cognitive model of new venture creation. Entrepreneurship Theory and Practice, 20(4), 25-40.

Busenitz, L. W., Gomez, C., \& Spencer, J. W. (2000). Country institutional profiles: Unlocking entrepreneurial phenomena. Academy of Management Journal, 43(5), 994-1003 Google.com/scholar.

Caputo, R. K., \& Dolinsky, A. (1998). Women's choice to pursue selfemployment: The role of financial and human capital of household members. Journal of Small Business Management, 36, 8-17.

Chimucheka, T. (2014). Entrepreneurship education in South Africa. Mediterranean Journal of Social Sciences, 5(2), 403.

Cossette, P. (2002). Cognition as a research objective in the scientific literature on small business and entrepreneurship. Working Paper Universite du Quebec.

Cuervo, A. (2005). Individual and environmental determinants of entrepreneurship. The International Entrepreneurship and Management Journal, 1(3), 293-311.

Da Rin, M., Di Giacomo, M., \& Sembenelli, A. (2011). Entrepreneurship, firm entry, and the taxation of corporate income: Evidence from Europe. Journal of public economics, 95(9-10), 1048-1066. 
Davidsson, P., \& Henrekson, M. (2002). Determinants of the prevalance of start-ups and high-growth firms. Small Business Economics, 19(2), 81-104.

Davidsson, P., \& Reynolds, P. D. (2005). Entrepreneurship research innovator, coordinator, and disseminator. Small Business Economics, 24(4), 351-358.

de Soto, Hernando. (2000). The mystery of capital.

Djankov, Simeon, et al. The regulation of entry. The Quarterly Journal of Economics 117.1 (2002): 1-37.

Dziri, M. H. (2013). Assessing the entrepreneurial ecosystem in Tunisia. Dissertations Massachusetts Institute of Technology.

Eden, D. (1973). Self-employed workers: A comparison group for organizational psychology. Organizational Behavior and Human Performance, 9(2), 186-214.

Eden, C., \& Ackermann, F. (1998). Analysing and comparing idiographic causal maps. In Managerial and organizational cognition: Theory, methods and research (pp. 192-209). Sage.

Evans, D. S., \& Jovanovic, B. (1989). An estimated model of entrepreneurial choice under liquidity constraints. Journal of Political Economy, 97(4), 808-827.

Fayolle, A. (2002). Insights to research on the entrepreneurial process from a study on perceptions of entrepreneurship and entrepreneurs. Journal of Enterprising Culture, 10(04), 257-285.

Franco, M., \& Haase, H. (2009). Entrepreneurship: an organisational learning approach. Journal of Small Business and Enterprise Development, 16(4), 628-641.

Gaston, Robert J. (1989) The scale of informal capital markets. Small Business Economics 1(3, 223-230.

Gompers, P. A., \& Lerner, J. (1999). What drives venture capital fundraising?. No. w6906. National Bureau of Economic Research.

Grilo, I., \& Thurik, R. (2005). Latent and actual entrepreneurship in Europe and the US: some recent developments. The International Entrepreneurship and Management Journal, 1(4), 441-459.

Henrekson, M., \& Sanandaji, T. (2011). The interaction of entrepreneurship and institutions. Journal of Institutional Economics, 7, 47-75 Google scholar.

Henry, J. D., et al. (2006). Theory of mind following traumatic brain injury: The role of emotion recognition and executive dysfunction. Neuropsychologia, 44(10), 1623-1628.

Hwang, H., \& Powell, W. W. (2005). Institutions and entrepreneurship. In Handbook of entrepreneurship research (pp. 201-232). Springer.

Kibler, Ewald, et al. (2012). (Work) life after work?: Older entrepreneurship in London-motivations and barriers.

Kristiansen, S., \& Indarti, N. (2004). Entrepreneurial intention among Indonesian and Norwegian students. Journal of Enterprising Culture, 12(01), 55-78.

Krueger, N. (1993). The impact of prior entrepreneurial exposure on perceptions of new venture feasibility and desirability. Entrepreneurship Theory and Practice, 18(1), 5-21.

Krueger, N. F., \& Carsrud, A. L. (1993). Entrepreneurial intentions: Applying the theory of planned behaviour. Entrepreneurship \& Regional Development, 5(4), 315-330.

Lam, C. W., Lim, S.-R., \& Schoenung, J. M. (2011). Environmental and risk screening for prioritizing pollution prevention opportunities in the US printed wiring board manufacturing industry. Journal of Hazardous Materials, 189(1-2), 315-322.

Lee, S.-H., Peng, M. W., \& Barney, J. B. (2007). Bankruptcy law and entrepreneurship development: A real options perspective. Academy of Management Review, 32(1), 257-272.

Lim, S. R., \& Schoenung, J. M. (2010). Toxicity potentials from waste cellular phones, and a waste management policy integrating consumer, corporate, and government responsibilities. Waste Management, 30(8-9), 1653-1660 Google scholar.

Luo, Y. (2002). Contract, cooperation, and performance in international joint ventures. Strategic Management Journal, 23(10), 903-919.
Lüthje, C., \& Franke, N. (2003). The 'making' of an entrepreneur: testing a model of entrepreneurial intent among engineering students at MIT. R\&d Management, 33(2), 135-147.

Masmoudi, Raef, \& Jihene Zouiten. (2007) The incubation models and the deployment strategy: Cases of incubator and seedbed of companies.

Matlay, H., Hytti, U., Stenholm, P., Heinonen, J., \& Seikkula-Leino, J. (2010). Perceived learning outcomes in entrepreneurship education. Education+ Training

McMullen, J. S., Bagby, D. R., \& Palich, L. E. (2008). Economic freedom and the motivation to engage in entrepreneurial action. Entrepreneurship Theory and Practice, 32(5), 875-895.

Mitchell, C. (2011). Doing visual research. Sage.

Mitchell, R. K., Smith, J. B., Seawright, K. W., \& Morse, E. A. (2000). Cross-cultural cognitions and the venture creating decision. Academy of Management Journal, 43(5), 974-993 Google scholar.

Mitchell, R. K., et al. (2002). Toward a theory of entrepreneurial cognition: Rethinking the people side of entrepreneurship research. Entrepreneurship Theory and Practice, 27(2), 93-104.

Mouhli, K., \& Paturel, R. (2019). Les mécanismes cognitifs à l'origine de la décision de reprendre du repreneur externe: une approche par le sensemaking. Revue de lEntrepreneuriat, 18(1), 171-201.

Nystrom, K. (2009). Economic growth and the quantity and quality of entrepreneurship. Entreprenorskaps Forum, Unga Foskarpriset.

Otache, I. (n.d.). Enhancing the effectiveness of entrepreneurship education: the role of entrepreneurial lecturers.

Ouanes, A., \& Rejeb, L. (2016). A hybrid approach for sleep stages classification. Proceedings of the Genetic and Evolutionary Computation Conference.

Özesmi, U., \& Özesmi, S. L. (2004). Ecological models based on people's knowledge: a multi-step fuzzy cognitive mapping approach. Ecological Modelling, 176(1-2), 43-64.

Parutel, \& Boukhris, A. (2015) La recherche participative en travail social: l'option d'une épistémologie et d'une méthodologie constructiviste. Les recherches-actions collaboratives, une révolution de la connaissance, 197-205.

Paturel, D. (2015). La recherche participative en travail social: l'option d'une épistémologie et d'une méthodologie constructiviste. Les recherches-actions collaboratives, une révolution de la connaissance, 197-205.

Paturel, R., \& Maalel, I. (2016). La performance des structures tunisiennes d'accomp a gnement des créat eurs d'entr eprises. Recherches en Sciences de Gestion, (2), 63-88 Google scholar.

Peng, M. W., et al. (2009). The institution-based view as a third leg for a strategy tripod. Academy of Management Perspectives, 23(3), 6381.

Randolph-Seng, B., et al. (2015). The microfoundations of entrepreneurial cognition research: toward an integrative approach. Foundations and Trends ${ }^{\circledR}$ in Entrepreneurship, 11(4), 207-335.

Raposo, M., \& Do Paço, A. (2011). Entrepreneurship education: Relationship between education and entrepreneurial activity. Psicothema, 23(3), 453-457.

Robinson, P. B., \& Sexton, E. A. (1994). The effect of education and experience on self-employment success. Journal of business Venturing, 9(2), 141-156.

Sachs, J. D., et al. (1995). Economic reform and the process of global integration. In Brookings papers on economic activity (Vol. 1995, pp. 11-18).

Samadi, A. H. (2018). Institutions and entrepreneurship in MENA countries. In Entrepreneurship ecosystem in the Middle East and North Africa (MENA) (pp. 53-93). Springer Google scholar.

Samadi, A. H. (2019). Institutions and entrepreneurship: unidirectional or bidirectional causality? Journal of Global Entrepreneurship Research, 9(1), 1-16. 
Schmitz, R., et al. (2009). TNFAIP3 (A20) is a tumor suppressor gene in Hodgkin lymphoma and primary mediastinal B cell lymphoma. Journal of Experimental Medicine, 206(5), 981-989.

Scott, W. R. (2008a). Approaching adulthood: the maturing of institutional theory. Theory and Society, 37(5), 427.

Scott, W. R. (2008b). Institutions and organizations: Ideas and interests (3rd ed.). Sage.

Shane, S. (1994). Why do rates of entrepreneurship vary over time? In Academy of Management Proceedings, vol. 1994, no. 1. Academy of Management.

Shapero, A., \& Sokol, L. (1982). The social dimensions of entrepreneurship. University of Illinois at Urbana-Champaign's Academy for Entrepreneurial Leadership Historical Research Reference in Entrepreneurship.

Shepherd, D. A., \& Patzelt, H. (2017). Researching entrepreneurial decision making. In Trailblazing in entrepreneurship (pp. 257-285). Palgrave Macmillan.

Smida, A., Khelil, N., \& de Caen, I. A. E. (2008). Repenser l'échec entrepreneurial des nouvelles entreprises. Proposition d'une typologie en s' appuyant sur une approche integrative. Recuperado, el-e4.

Smith, J. B., Mitchell, J. R., \& Mitchell, R. K. (2009). Entrepreneurial scripts and the new transaction commitment mindset: Extending the expert information processing theory approach to entrepreneurial cognition research. Entrepreneurship Theory and Practice, 33(4), 815-844.

Sobel, R. S. (2008). Testing Baumol: Institutional quality and the productivity of entrepreneurship. Journal of Business Venturing, 23(6), 641-655.
Stenholm, P., Acs, Z. J., \& Wuebker, R. (2013). Exploring country-level institutional arrangements on the rate and type of entrepreneurial activity. Journal of Business Venturing, 28(1), 176-193 Google scholar.

Stephen, L. (2005). Zapotec women: Gender, class, and ethnicity in globalized Oaxaca. Duke University Press.

Urbano, D., \& Guerrero, M. (2013). Entrepreneurial universities: Socioeconomic impacts of academic entrepreneurship in a European region. Economic Development Quarterly, 27(1), 40-55.

Van Gelderen, M., \& Jansen, P. (2006). Autonomy as a start-up motive. Journal of Small Business and Enterprise Development.

Van Stel, A., Storey, D. J., \& Thurik, A. R. (2007). The effect of business regulations on nascent and young business entrepreneurship. Small business economics, 28(2), 171-186.

Verstraete, T. (1996). La cartographie cognitive: outil pour une démarche d'essence heuristique d'identification des facteurs Clés de Succès. Conférence Internationale de Management Stratégique.

Vesper, K. H., \& Gartner, W. B. (1996). Measuring progress in entrepreneurship education. Journal of Business Venturing, 12(5), 403-421.

Webb, E., \& Weick, K. E. (1979). Unobtrusive measures in organizational theory: A reminder. Administrative Science Quarterly, 24(4), 650-659.

Whitley, R. (1999a). Divergent capitalisms: The social structuring and change of business systems. OUP.

Whitley, E. A. (1999b). Understanding participation in entrepreneurial organizations: some hermeneutic readings. Journal of Information Technology, 14(2), 193-202.

Xavier, R. O. T. H. (2013). Georges Canguilhem et l'unité de l'expérience. Juger et agir (1926-1939). Paris, Vrin. 